Marcin Pomarański

UMCS, Lublin

\title{
NATIONAL REFERENDUMS \\ IN HUNGARY AND ALBANIA: A COMPARATIVE PERSPECTIVE ${ }^{1}$
}

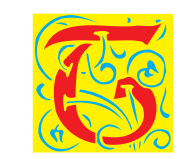

he political transformation of 1989 in Central and Eastern Europe was a catalyst for democratic change in this part of the world. Political enthusiasm of new power elites, as well as ordinary citizens in the post-communist countries has resulted in the adaptation of new legal systems, new economic development patterns and West-European political culture. These changes included instruments of direct democracy such as national referendum. However, in particular countries of the region the latter has not been proceeded proportionately. Different dynamics of social and political changes in various countries have substantially contributed to the process of shaping post-authoritarian civil societies. Citizens in these societies were conscious of their fundamental rights and demanded direct participation in the process of exercising power. On the other hand, these dynamics also played a key role in shaping the attitudes of new political leaders in Central and Eastern Europe, determining their views on the importance of procedures such as the national referendum. The ability to achieve a balanced compromise between societies and their leaders on the citizens' participation in decision-making process is a predictor of political stability and a measure of the strength of democratic principles in this part of the world even today. The aim of this paper is a comparative analysis of legislative solutions and practical application of direct democracy in Hungary and Albania after 1989. The current position of the nationwide referendum institution in both countries is determined by a combination of historical and political conditions, both before and after the political transformation, which

1 The article is the result of research Project No. 2014/15/B/HS5/01866 founded by the National Science Centre. 
are reflected in specific legislative solutions, as well as in the referendum activity of Albanians and Hungarians. The object of our attention will be especially institutional and legal differences determining the development (or regression) of the direct democracy in those countries. Main thesis of the article is the opinion that Hungary and Albania, regardless of their common experiences, represent two different models for adaptation of direct democracy solutions.

\section{Common experiences}

The first legal application of the direct democracy principles in Hungary and Albania was introduced during the communist period. In the Hungarian People's Republic the Constitution of 1949 introduced a paragraph providing the Presidential Council - a collegiate head of state, the right to have issues of national importance to vote by a nationwide "plebiscite." ${ }^{2}$ In the case of the People's Socialist Republic of Albania a similar measure (called "national referendum") was guaranteed in 1976, but was provided only for "working class." 3 Although in both cases legislative solutions have the colorable and improvised character. In both cases as well, the principles of direct democracy that actually functioned were introduced by amendments to the communist constitutions in the moments of political transformation in 1989 (Hungary) and 1991 (Albania).

In the case of Hungary, legal solutions established by the "Law on Referendum and Popular Initiative" of 1989 proved to guarantee citizens the possibility of real influence on political decision-making process. ${ }^{4}$ According to the International Institute for Democracy and Electoral Assistance the law from this period was uncommonly liberal, overtaking solutions of most European countries. ${ }^{5}$ However, the fact of extremely late adoption the new Constitution (which appeared in 2011, so 22 years after the fall of the communist regime) by the Hungarian National Assembly contributed to the progressive reduction

2 Constitution of the People's Republic of Hungary, Act XX of 1949, Hungary, article 20.

3 The Constitution of The People's Socialist Republic of Albania, Law no. 5506 of 1976, Albania, article 5.

${ }^{4}$ Law on Referendum and Popular Initiative, Act XVII of 1989, Hungary.

5 K. Medve, "Direct democracy in the Republic of Hungary," in: Direct Democracy: The International IDEA Handbook, ed. V. Beramendi et al., Stockholm: International Institute for Democracy and Electoral Assistance, 2008, 99. 
of direct democracy procedures. Two another amendments to the "old" Constitution, as well as two further electoral laws and five Constitutional Court's decisions have made the referendum a sensitive and strictly political issue, affecting the stability of the direct democratic law in the eyes of public opinion. Progressive fatigue of the dispute, as well as a disproportion in evaluating the mechanisms of direct democracy have coined strong conviction of the Hungarian political elite to limit the possibility of using national referendum in practice. Fundamental achievement of this decision was the "new" Constitution of $2011 .^{6}$

Convergent socio-political experiences characterized Albanian electoral system from the last decade of the $20^{\text {th }}$ century. Democratic amendments to the communist law, as well as the new Constitution of 1998 were formed in the atmosphere of strong conflict between the political parties and massive social unrest, which took almost a form of civil war. Political turmoil, which resulted in six modifications of Albanian electoral system after 1990 effectively limited the ability to use the instruments of direct democracy in the process of decision-making. ${ }^{7}$ Notwithstanding the provisions of law and the formal administrative decisions guaranteeing the possibility of convening national referendum, the government in Tirana, as well as oppositional political elites of this country did not present special interest in procedures of exercising the power with the help of direct democracy. Moreover, apathetic absence of such involvement is also characteristic to the Albanian citizens, which means that the instruments of direct democracy in this country are practically unused.

\section{Legislative divergences}

The first fundamental difference between the Albanian and Hungarian legislation on national referendum is a range of content included in (or excluded from) the procedure of direct democracy. The Albanian law defines these issues only in general and vague way. The Constitution of the Republic of Albania from 1998 states that "the people . . . have the right to a referendum for the

6 The Fundamental Law of Hungary, dated 25.04.2011.

7 V. Stojarová et al., Political Parties in the Central and Eastern Europe. Central and Eastern Europe Regional Report Based on Research and Dialogue with Political Parties, Stockholm: International Institute for Democracy and Electoral Assistance, 2007, 39-40. 
abrogation of a law, and to request the President of the Republic to call a referendum on issues of special importance." Only issues related to the territorial integrity of the republic, the limitation of fundamental human rights and freedoms, the budget, taxes and financial obligations of the state, the imposition or lifting of a state of emergency, as well as a declaration of war or peace, and amnesty cannot be submitted to the referendum. ${ }^{8}$

At first glance, the Hungarian legislation is also quite imprecise in the question of the range of content included in the procedure of direct democracy. The Hungarian constitution of 2011 specifies that the referendum "may be held about any matter falling within the functions and powers of the National Assembly." But it is much more specific in the list of issues excluded from the national referendum. The constitution itemized: “(a) any matter aimed at the amendment of the Fundamental Law; (b) the contents of the Acts on the central budget, the implementation of the central budget, central taxes, duties, contributions, customs duties or the central conditions for local taxes; (c) the contents of the Acts on the elections of Members of the National Assembly, local government representatives and mayors, or Members of the European Parliament; (d) any obligation arising from international treaties; (e) personal matters and matters concerning the establishment of organizations within the competence of the National Assembly; (f) the dissolution of the National Assembly; (g) the dissolution of a representative body; (h) the declaration of a state of war, state of national crisis or state of emergency, furthermore on the declaration or extension of a state of preventive defense; (i) any matter related to participation in military operations; and ( $j$ ) the granting of general pardons."

The key divergence between the Albanian and Hungarian law on referendum includes the problem of changing the constitution. The Albanian Constitution of 1998 clarified by rules of "2003 The Electoral Code" mentions as one of the types of direct democracy procedure the constitutional referendum. It can be ordered only by the Albanian parliament by a two-thirds majority of all its members at the request of one fifth of the deputies. In contrast, the Hungarian law completely excludes the possibility of changing the Constitution by national referendum. However, the decision no. 25/1999 of the Constitutional Court has confirmed that prohibition relates only to constitutional

8 The Constitution of the Republic of Albania, Law no. 8417 of 1998, articles 150, 151.

9 The Fundamental Law of Hungary, article 8. 
amendments initiated by citizens, and not proposed by Parliament. Theoretically, the amendments made by the latter could be the issue of referendum. However, the problem of changing the Hungarian constitution stays the exclusive competence of National Assembly. ${ }^{10}$

The role of Parliament in the procedure of national referendum is the second fundamental difference between the Albanian and Hungarian legislation on direct democracy. The Albanian act "The Electoral Code" from 2003 decides on initiating the general referendum on the proposal of not less than one-fifth of the deputies, as well as on holding of the procedure by the Assembly. Even though the use of this instrument does not require approval of legislative majority in every situation. In the case of national referendum on the issue of special importance the decision can be taken also by the president of the republic, after receiving a favorable opinion of the Constitutional Court. ${ }^{11}$ Thus, the head of state's role in the process of setting up the referendum is exactly alike the function of Parliament. Moreover, the Assembly is vested with its own and exclusive competences in the issues of direct democracy, as in the aforementioned procedure of national referendum on changing the constitution.

In the case of Hungary, the role of Parliament in the procedure of direct democracy has been gradually minimized. "Law on National Referendum and Popular Initiative" in 1998 specified functions of the National Assembly in general referendum. The unicameral body received only two main competences: 1) initiation the procedure at the request of one third of the elected Members of the Parliament, as well as 2) obligation on ordering the referendum supported by at least 200000 constituents or considering the launching of it, if initiators would gather fewer than 200000 but more than 100000 signatures. Such a position of the Hungarian parliament was restricted in the last years by the "Fundamental Law of Hungary." 12 Under the new constitution adopted and promulgated in April 2011 the National Assembly lost the entitlement to order a referendum on the initiative of its deputies and was given only the second competence - launching of the procedure of direct democracy. ${ }^{13}$

${ }^{10}$ L. Komaromi, "Milestones in the history of direct democracy in Hungary," Iustum Aequum Salutare IX.4, 2013, 56.

11 The Electoral Code of the Republic of Albania, Law no. 9087 of 2003, Albania, articles $118-132$.

12 Law on National Referendum and Popular Initiative, Act III of 1998, Hungary.

13 The Fundamental Law of Hungary, article 8. 
Mandatory national referendum is another difference between the practice of direct democracy in Albania and Hungary. In the case of the first country, all forms of general referendum are optional. There are not any legal provisions for mandatory referendum at the national level. For each project of direct democracy decisive vote belongs to the President of the Republic, as well as for the Central Election Commission and Constitutional Court. In the case of the latter country, the law allows the existence of a special procedure: the obligatory referendum. It does not require any formal approval from the parliament or the president of the republic. The mandatory procedure of direct democracy in Hungary requires a twofold increase in the number of supporters (200 000 signatures) compared to the optional referendum, but it does not require the support of the government administration. Its only condition is the need to fulfill the technical requirements of the application (as the written form of the proposal) specified by the Magyar National Election Commission.

\section{Practical disaccords}

The role of a nation in the practice of activating the referendum, which is the consecutive important difference between the Albanian and Hungarian legislation on direct democracy, presents a totally different way. In the case of the prior country you can observe a tendency to minimize the role of the people in the lawmaking process, including the procedures of direct democracy. As Aurela Anastasi, the Professor of Constitutional Law at the University of Tirana noticed citizens' initiatives of a referendum are considered by Albanian politicians "more as an intervention in the legislative power, or as complementary to that." ${ }^{14}$ A proof of this is the whole list of legal ambiguities, such as the unclear role of the Central Election Commission in the organization of the national or local referendum, as well as the complicated process of initiating procedures of direct democracy by citizens. Their role is to discourage people from "interfering in the affairs of legislation." This is a completely different approach from the legal solutions adopted in Hungary, where appropriate number of citizens have the right to decide on the establishment of a national referendum, without the approval of the parliament or the president.

${ }^{14}$ A. Anastasi, "Law making citizens' initiatives and the constitutional law in Albania (legislation, jurisprudence, practice)," Krytyka Prawa 6, 2014, 81-82. 
A tangible proof of such an approach to the role of the nation in the practice of activating the referendum is the divergence in the limits of votes required to determine the legality of the procedures of direct democracy. Albanian constitution allows an optional referendum at the request of 50000 people, which is ca. $2 \%$ of the entire population. ${ }^{15}$ In Hungary the same right is already entitled to 100000 citizens. But it is only about $1 \%$ of the entire population. ${ }^{16}$ In accordance with Magyar law the doubled number of the citizens has already the right to decide on the procedure of national referendum without the approval of any office or legislative power.

All of the above-mentioned divergences are reflected in the practice of using national referendum procedures. Regardless of legislative guarantees, as well as the political declaration of the government's representatives in Tirana, the atmosphere for conducting direct democracy in Albania is unfavorable. Since the fall of communism in the early 90s of the twentieth century, a national referendum was applied there only three times. Moreover, all three were organized under the provisions of Constitutional Act of 1991. No referendum was held after the adoption of the new Constitution in 1998, which is a clear example of the lack of interest in using direct democracy by the Albanian political authorities. Organized referenda concerned only the key political issues. In two cases, the aim was to achieve social acceptance of the proposed constitutional laws (1994, 1998), and the third - to express opinion on the selection of the preferred system of government (1997). ${ }^{17}$

The practice of using direct democracy in the Hungarian legislative procedure is much more common. As the International Institute for Democracy and Electoral Assistance emphasizes, the right on referendum applicable for more than 20 years in the country was "exceptionally liberal and surpassed the Corresponding Provisions of many of the West European parliamentary Democracies." Direct democracy procedures partly limited by the constitution of 2011, resulted in the relative popularity of the institution of national referendum. Seven national referendums on thirteen questions have taken place since 1989. Some of them concerned the fundamental issues from the point of view of the state as the way to select the president of the republic $(1989,1990)$, membership in NATO (1997) and in the European Union (2003). However, some

15 The Electoral Code of the Republic of Albania, article 150.

16 The Fundamental Law of Hungary, article 8.

17 A. Kume, "Referendums - analysis and assessment of the Albanian legislation," Interdisciplinary Journal of Research and Development 1 (January 2014), 67-68. 
events take more specific issues: the law that enables ethnic Hungarians with non-Hungarian citizenship (2004), patient care exemption from daily hospital fees, as well as tuition fees for students in state-subsidized higher education (2008). The most recent national referendum was conducted in October 2016 and was related to the European Union's migrant resettlement plans. Controversy undertaken in the framework of this issue, as well as the fact of voting the idea when it was practically obsolete, forced to treat the last example of direct democracy in Hungary only in terms of "plebiscite popularity for Victor Orban's government." 18

The comparative analysis of the legislation and practice in the procedure of national referendum in Albania and Hungary after 1989 clearly shows that similar historical, social and political experiences have not led to similar solutions in the context of direct democracy. In the case of Albania, the lack of good will from the government, as well as the citizens' distance from national referendum decided about minimal role of direct democracy in the process of governance, at least in the first years after transformation. In recent years there has been a positive change in the issue in the political elites, as well as ordinary citizens' way of thinking. The symbol of positive change can be 2014 when the Albanian Central Election Commission received over 130 initiatives to launch local referenda. In the case of Hungary, the process was completely opposite. After the initial feeling of delighted approval of direct democracy, which expressed itself in the liberal legislation and impressive activity of the society in the practice of national referenda, there has been a process of gradual renouncement from these principles. Gradual increase in the range of issues that cannot be the subject of a referendum, as well as the enhancing complication of the rules for initiating the national referendum which ultimately materialize in Constitution of 2011 have been a discouragement for the citizens to use this procedure.

18 Hungarian National Election Office website (Nemzeti Választási Iroda), http:// valasztas.hu/ (30.09.2016). 